\title{
Contribution of in Vivo Experimental Challenges to Understanding Flat Oyster Ostrea edulis Resistance to Bonamia ostreae
}

\author{
Benjamin Morga ${ }^{1}$, Tristan Renault ${ }^{2}$, Nicole Faury ${ }^{1}$, Sophie Lerond ${ }^{1}$, Céline Garcia ${ }^{1}$, \\ Bruno Chollet ${ }^{1}$, Jean-Pierre Joly ${ }^{1}$, Sylvie Lapègue ${ }^{1}$, Estelle Harrang ${ }^{1}$ and Isabelle Arzul ${ }^{1 *}$ \\ ${ }^{1}$ Laboratoire de Génétique et Pathologie des Mollusques Marins, IFREMER Institut Français de Recherche pour l'Exploitation \\ de la Mer, La Tremblade, France, ${ }^{2}$ Département Ressources Biologiques et Environnement, IFREMER Institut Français de \\ Recherche pour l'Exploitation de la Mer, Nantes, France
}

\section{OPEN ACCESS}

Edited by:

Brice Rotureau,

Institut Pasteur, France

Reviewed by:

Bojan Hamer,

Rudjer Boskovic Institute, Croatia

Ryan Carnegie,

VA Institute of Marine Science,

United States

*Correspondence:

Isabelle Arzul

isabelle.arzul@ifremer.fr

Received: 20 January 2017 Accepted: 21 September 2017

Published: 06 October 2017

Citation:

Morga B, Renault T, Faury N,

Lerond S, Garcia C, Chollet B, Joly J-P, Lapègue S, Harrang E and Arzul I (2017) Contribution of in Vivo

Experimental Challenges to Understanding Flat Oyster Ostrea edulis Resistance to Bonamia ostreae.

Front. Cell. Infect. Microbiol. 7:433 doi: 10.3389/fcimb.2017.00433
Bonamiosis due to the parasite Bonamia ostreae has been associated with massive mortality outbreaks in European flat oyster stocks in Europe. As eradication and treatment are not possible, the control of the disease mainly relies on transfer restriction. Moreover, selection has been applied to produce resistant flat oyster families, which present better survival and lower prevalence than non-selected oysters. In order to better understand the mechanisms involved in resistance to bonamiosis, cellular and molecular responses of 2 oyster groups (selected oysters and wild-type oysters) were analyzed in the context of experimental injection and cohabitation infections. Cellular responses including non-specific esterases detection, ROS production and phagocytosis activity were analyzed by flow cytometry. Four genes homologous to those shown to be involved in immunity were selected (Inhibitor of apotosis OelAP, Fas ligand OeFas-ligand, Oe-SOD, and OeEc-SOD) and monitored by quantitative reverse-transcription PCR (qRT-PCR). Infected oysters showed higher phagocytosis activity than controls. Infected selected oyster show a lower phagocytosis activity which might be a protection against the parasite infection. The expression of OelAP and OeFas-ligand gene was significantly increased in selected oysters at 5 days post-injection. OelAP gene expression appeared to be significantly increased in wild-type oysters at 8 days post-injection. Our results suggest that resistance to bonamiosis partly relies on the ability of the oysters to modulate apoptosis.

Keywords: Bonamia ostreae, protozoan, Ostrea edulis, resistance, experimental infection, haemocytes, gene expression, apoptosis

\section{INTRODUCTION}

The European flat oyster Ostrea edulis is an endemic species to European and North African coasts and is found from Norway to Morocco as well as in the whole Mediterranean and Black seas (Jaziri, 1985). European production of O. edulis has shown a drastic decline from about 30,000 t in 1961 to less than 2,000 t nowadays in Europe (Food and Agriculture Organization of the United Nations, 2010). This decrease is mainly explained by the rapid spread and high impact of two parasitic diseases, due to Marteilia refringens and Bonamia ostreae. 
The parasite Bonamia ostreae was first described in 1979 by Pichot et al. (1979), in the context of spat mortality event in French Brittany. Bonamia ostreae is an intracellular rhizarian protozoan affiliated to the phylum Haplosporidia (Arzul and Carnegie, 2015; Sierra et al., 2016).

The disease has been associated with haemocyte infiltration in the connective tissue of the gills, mantle and digestive gland in relation with the multiplication of $B$. ostreae (Balouet et al., 1983; Cochennec-Laureau et al., 2003). Mortalities are mainly observed in two-year old oysters (Culloty and Mulcahy, 1996) although younger individuals ( $0-1$ year more) and larvae have been shown susceptible to the infection (Cavalier-Smith and Chao, 2003; Lynch et al., 2005; Lallias et al., 2008; Arzul et al., 2011).

Although methods for in vitro cultivation of the parasite are lacking, a protocol for parasite purification from infected oysters (Mialhe et al., 1988) enables in vitro and in vivo studies on interactions between $B$. ostreae and its host cells, the haemocytes (Mourton et al., 1992; Morga et al., 2009, 2010, 2011a,b, 2012). This protocol has notably allowed the implementation of experimental infection trials by injecting the parasite into flat oysters (Mialhe et al., 1988; Hervio et al., 1995) or by cohabiting source oysters injected with a known number of $B$. ostreae cells and healthy oysters (Culloty et al., 1999; Lallias et al., 2008).

Selective breeding programs were initiated in France and Ireland in the 90's, with the main objective of producing flat oysters more resistant to bonamiosis (Naciri-Graven et al., 1998; Culloty et al., 2004). In France, genetic selection was applied through inoculation tests and field testing, the surviving oysters being used as breeders to produce the next generation (NaciriGraven et al., 1998). As a result, different selected families have been produced in Ifremer facilities (La Tremblade, CharenteMaritime, France) and showed enhanced survival and lower prevalence of the parasite compared with control wild-type oysters in B. ostreae contaminated areas (Lapègue et al., 2004).

The flat oyster Ostrea edulis and its parasite Bonamia ostreae represent a well-suited model to study host-pathogen interactions. Previous studies demonstrated that the parasite B. ostreae was internalized after $30 \mathrm{~min}$ of contact with haemocytes and was not degraded after phagocytosis (Chagot et al., 1992; Mourton et al., 1992). Hervio et al. (1991), reported that the parasite possesses catalytic enzymes and acid phosphatase which could inhibit haemocyte activities. Intracellular parasites have developed sophisticated strategies to escape host defense mechanisms, thereby finding unique niches where they can survive, and from which they can establish successful infections. Recently in vitro infections were performed in order to study the cellular and molecular responses of haemocytes from selected and wild-type flat oyster Ostrea edulis against the parasite B. ostreae (Morga et al., 2009, 2011b). Moreover, the identification of some genes characterized by $\mathrm{SSH}$ contributed to better understand the immune response of Ostrea edulis against the intracellular parasite (Morga et al., 2012).

In vitro infections are widely used in order to describe the interaction between the flat oyster and its parasite B. ostreae (Chagot et al., 1992; Mourton et al., 1992; Morga et al., 2009,
2010; Gervais et al., 2016). However, the knowledge of the cellular and molecular responses in selected oysters is poorly studied especially in the context of in vivo experiments. In vitro infections were previously used to identify cellular and molecular mechanisms involved in the response of the haemocytes to the infection of the parasite $B$. ostreae. However, such experiments do not consider early infection steps including the interaction between mucus and parasite. On the contrary, in vivo infections are more similar to natural infections.

Considering the need to better understanding interactions between flat oysters and the parasite Bonamia ostreae, two types of experimental challenges were carried out by injecting parasites and by exposing non-infected oysters with healthy ones. Two groups of oysters were challenged in the context of these trials: flat oysters selected for their better resistance to bonamiosis and wild-type oysters collected from a bonamiosis endemic French area. These experimental infections allowed us to better describe the pathogenesis and the response of the oyster to the infection. Cellular and molecular responses of both oyster groups were analyzed by histology, and flow cytometry and by quantitative reverse-transcription PCR (qRT-PCR).

\section{MATERIALS AND METHODS}

\section{Biological Material Oysters}

Eighteen to twenty four months $(n=850)$ flat oysters Ostrea edulis were collected from Quiberon Bay (Southern Brittany, France), a bonamiosis endemic zone, and were acclimatized in Ifremer's facilities (La Tremblade, Charente Maritime, France) over 30 days. These oysters are called "wild-type oysters" thereafter.

The oysters subsequently called "selected oysters" were obtained from the progenitors identified in a previous program of selection (Naciri-Graven et al., 1998). Flat oysters were produced in the IFREMER's hatchery from Argenton (Brittany, France). Then, 18 month old oysters were acclimatized in IFREMER's facilities in La Tremblade (Charente Maritime, France) over 30 days.

\section{Haemolymph Collection}

Haemolymph was withdrawn from the adductor muscle sinus using a $1 \mathrm{ml}$ syringe equipped with a needle $(0.40 \mathrm{~mm} \times$ $90 \mathrm{~mm}$ ). To eliminate debris the haemolymph samples were filtered through $60 \mu \mathrm{m}$ nylon mesh and hold on ice to prevent cell aggregation. The volume of haemolymph collected from each oyster was approximately $1 \mathrm{ml}$. Haemolymph samples were pooled and haemocytes counted using a Malassez-cell.

\section{Parasite Purification}

Bonamia ostreae was purified as described in Morga et al. (2009). Briefly, heavily infected oysters were selected by examination of heart tissue imprints using light microscopy. After homogenization of all the organs except the adductor muscle, parasites were concentrated by differential centrifugation on sucrose gradients and then purified by isopycnic centrifugation 
on a Percoll gradient. Finally, the purified B. ostreae cells were suspended in FSW and counted using a Malassez-cell.

\section{Experimental Infections}

\section{Experimental Infection by Injection}

The experimental design consisted of 12 tanks (6 for selected oysters and 6 for wild-type oysters) containing 60 oysters each. Purified parasites $\left(2.2 \times 10^{5}\right.$ per individual $)$ were injected into 180 selected oysters and 180 wild-type oysters. The same amount of oysters was injected with $100 \mu \mathrm{L}$ of filtered sea water (FSW). Injection was performed into the adductor muscle after "anesthesia" using $\mathrm{MgCl}_{2}(200 \mathrm{~g} / \mathrm{l})$ (for injection oyster were not notched only anesthetized). Flat oysters were then maintained in $120 \mathrm{~L}$ tank supplied with a constant flow of seawater $150 \mathrm{~L}$ $\mathrm{h}^{-1}$ enriched in phytoplankton (Skeletonema costatum, Isochrisis galbana, Chaetoceros gracialis and Tetraselmis suecica).

Ten oysters were collected from each tank $12 \mathrm{~h}, 3,5,8,15$, and 30 days after parasite injection. Haemolymph was withdrawn from the adductor muscle of each oyster and haemolymph samples (10) were pooled for each tank and each collecting date. Pools of haemolymph were analyzed by flow cytometry and real time PCR (Figure 1A).

\section{Experimental Infection by Cohabitation}

The experimental design consisted of 4 tanks, 2 tanks containing 100 selected oysters each and 2 tanks containing 100 wildtype oysters each. Cohabitation was performed between 100 challenged oysters and 60 experimentally infected oysters per tank. Oysters (selected and wild) were previously infected by injection of $1 \times 10^{6}$ purified parasites per oyster as previously described.

The experiment lasted 6 months, oyster mortality was checked daily and dead oysters were analyzed by heart imprint. Twenty five challenged oysters were collected from each tank after 4 and 5 months of cohabitation. Remaining oysters were sacrificed at the end of the experiment (6 months postcohabitation). Haemolymph was withdrawn from the adductor muscle of each oyster and maintained on ice. Infection status was established by heart imprint and haemolymph samples were pooled according to the type of oysters (selected/wild-type) and the status of the oysters (infected or non-infected). Pools of haemolymph were analyzed by flow cytometry and real time PCR (Figure 1B).

\section{Detection of Bonamia ostreae Heart Imprint}

In the context of the cohabitation experiments each challenged oyster was characterized by heart imprint. Heart imprint was performed on each sampling oyster. After dissecting out, drying the ventricle on absorbent paper, several imprints were carried out on glass slides. After air drying for $2 \mathrm{~min}$, the slide was then stained with Hemacolor (Merck). Slides were observed under a light microscope and the level of infection with the parasite was characterized according to Hervio et al. (1995) into the following categories: - 0 negative results (B0-) when no parasite was detected, - I low infections (B0+) when five or fewer parasites were observed, - II moderate infections $(\mathrm{B} 0++)$ when around one parasite per microscopic field of view was detected, - III heavy infections $(\mathrm{B} 0+++)$ when several or numerous parasites were observed in each microscopic field of view.

\section{Histology}

In the context of the injection experiments, for each oyster, a section of tissues including gills, mantle and digestive gland was placed in Davidson's fixative for $24 \mathrm{~h}$ and embedded in paraffin. Sections $(5 \mu \mathrm{m})$ were placed in an oven at $60^{\circ} \mathrm{C}$, deparaffinized in xylene for $10 \mathrm{~min}$, and stained with a conventional hematoxylin and eosin staining. Intensity of infections with Bonamia ostreae was established as following-(I) null infection (0) when no $B$. ostreae was detected in the section (BO-); -(II) light infection when one to two $B$. ostreae were present in each infected haemocyte, rarely up to $4(\mathrm{BO}+)$; - (III) moderate infection when $B$. ostreae occurred in various foci of haemocytic infiltration and haemocytes enclosing few (1-4) parasites coexisted with haemocytes bearing up to 10 parasites $(\mathrm{BO}++)$; - (IV) heavy infection when $B$. ostreae was widespread throughout host organs and numerous parasites occurred in each infected haemocyte, (even more than 20) $(\mathrm{BO}+++$ ).

\section{Cellular and Molecular: Haemocyte Responses \\ Flow Cytometry}

Cell mortality, non-specific esterase activities, ROS (Reactive oxygen species) production and fluorescent bead phagocytosis were measured by flow cytometry using an EPICS XL 4 (Beckman Coulter) according to previously published protocols (Morga et al., 2009).

\section{Quantitative Reverse-Transcription PCR (qRT-PCR)}

Extraction of total RNA and real-time quantitative PCR reactions were performed according to previously published protocol (Morga et al., 2010, 2011a,b, 2012). The expression of tested genes was normalized using the elongation factor 1 alpha (EU651798) as housekeeping gene (Morga et al., 2010). In the context of injection, calibrator consisted of samples collected at $12 \mathrm{~h}$ postinfection. For cohabitation experiment, the calibrators were noninfected oysters (Bustin et al., 2009). Fold units were calculated using the method described by Pfaffl (2001) (gene expression; up-regulated $>1$ and down regulated $<1$ ). Genes studied in both experiment were Inhibitor of apoptosis OeIAP, Fas ligand OeFas-ligand, cytoplasmic superoxyde dismutase Oe-SOD and extracellular superoxyde dismutase OeEc-SOD.

\section{Statistical Analysis}

Flow cytometry results were analyzed using ANOVA test. Values were converted into $r$ angular arcsinus $\sqrt{ }(\%$ of positive cells $)$ before analysis to ensure respect of a priori assumptions of normality and homogeneity ANOVA analyses were performed using XLSTAT-Pro ${ }^{\circledR}$ version 7.5.3 software. In the case of rejection of $\mathrm{H} 0$, an a posteriori Tukey test was used to compare differences between means. Real time PCR were analyzed using ANOVA test. 


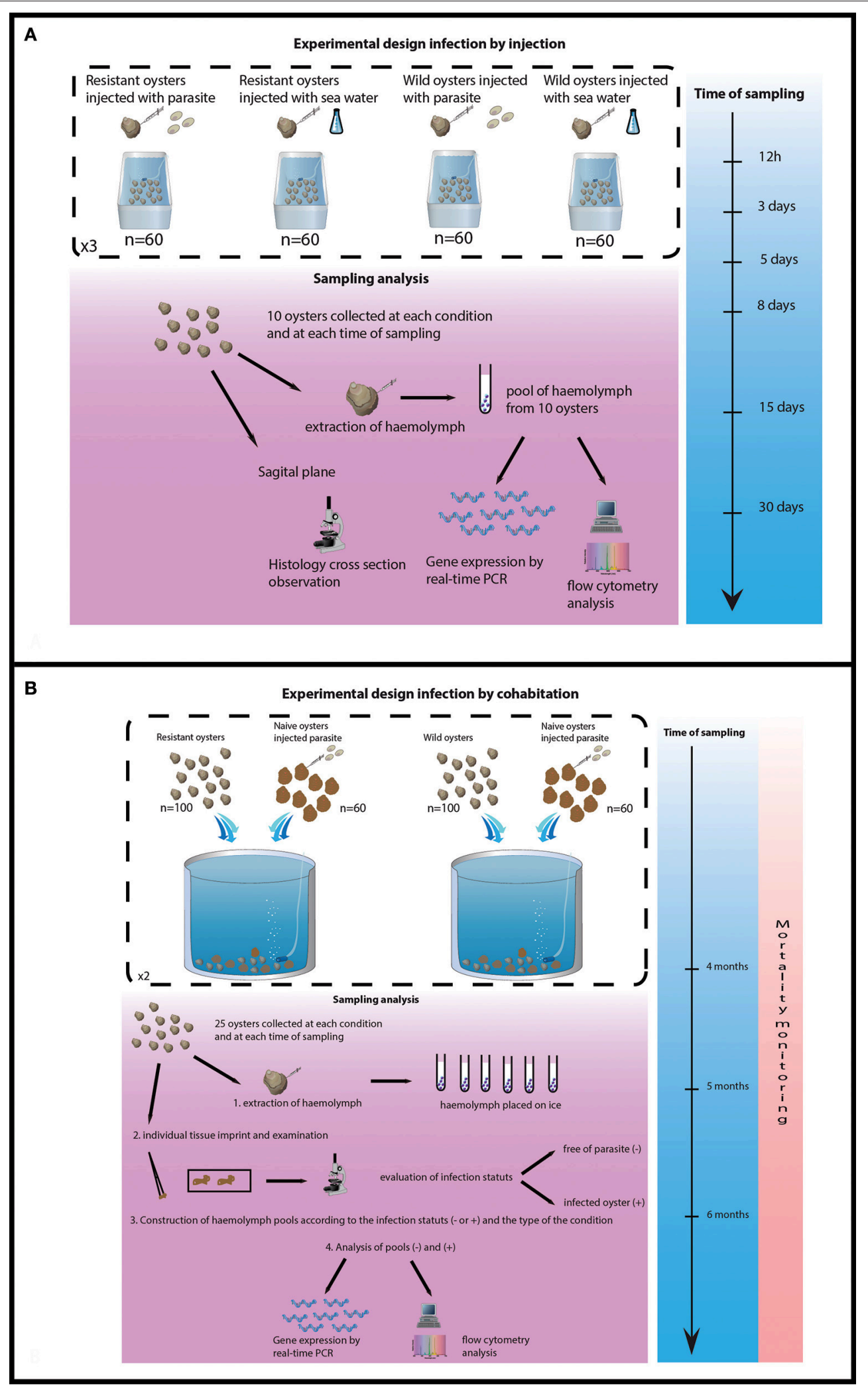

FIGURE 1 | Experimental design of both trials. (A) Experimental design of infection by injection. (B) Experimental design of infection by cohabitation. 


\section{RESULTS}

\section{Experimental Infection by Injection Detection of Bonamia ostreae}

Examination of histological sections allowed detecting Bonamia ostreae in challenged flat oysters. More infected oysters were reported among the wild-type group (24 positive oysters/120 analyzed oysters: $20 \%$ ) than in selected oysters (6 positive oysters/120 oysters analyzed: 5\%) (Table 1A). Among infected wild-type oysters, 9 showed low infection level (Bo+), 4 appeared moderately infected $(\mathrm{Bo}++)$ and 11 displayed high infection levels $(\mathrm{Bo}+++)$. Among infected selected oysters, 4 showed low infection level (Bo+) and 2 oysters were found moderately infected $(\mathrm{Bo}++)$ (Table 1A). While the number of infected oysters decreased in time for the selected oysters, more infected oysters were found at the end of the experiment in the wild group (Table 1B).

In infected selected oysters, infection level was generally low (few infected zones and few parasite cells observed per infected area) and the parasite was mainly detected in gills and digestive gland. On the contrary, infected wild oysters generally displayed high infection levels (with parasites widely spread in the different organs including the digestive gland, gills, mantle and gonad. Haemocyte infiltration could sometimes be observed in infected zones in wild oysters (Figure 2).

\section{Flow Cytometry}

Haemocyte mortality rates did not present significant differences between tested conditions and never exceeded $5 \%$.

Haemocytes from wild-type challenged oysters showed higher non-specific esterase activities $(p<0.0001)$ than non-infected 30 days post-injection (Figure 3A) and higher ROS production than controls 5 days $(p<0.016)$ post-injection.

Haemocytes from selected challenged flat oysters produced less ROS than controls 8 days post-injection $(p<0.014)$ (Figure 3B).

Fluorescent bead phagocytosis was lower in selected infected oysters compared with non-infected ones particularly at $12 \mathrm{~h}$ $(p<0.037)$ and 5 days $(p<0.037)$ post-injection. On the contrary, wild-type challenged oysters showed higher fluorescent bead phagocytosis compared with non-challenged ones at $12 \mathrm{~h}$ post-injection (Figure 3C).

\section{Oyster Gene Expression}

FSW (filtered sea water) injected oysters did not present significant gene expression modulation whatever the oyster group (wild or selected) was (Figures 4A,B).

Selected infected oysters showed a significant up regulation $(p<0.0001)$ of Oe-IAP and Oe-Fas ligand gene expression, especially 5 days post-injection while infected wild oysters displayed a down regulation of these genes (Figure 4). In wildtype flat oysters injected with the parasite, the expression of OeFas-ligand gene expression was significantly down regulated $(p<0.005)$ after 5 and 30 days $(p<0.006)$ (Figure 5).

SOD expression appeared down regulated at 3 days postinfection in selected infected oyster is down regulated and up regulated at 5 days in wild infected oyster expression.
In contrast, Ec SOD was down regulated at 5 days postinfection in infected selected oysters significantly up regulated at 15 days in wild oysters.

\section{Experimental Infection by Cohabitation} Mortality Monitoring and Bonamia ostreae Detection Selected oysters showed a significant $(p<0.05)$ less mortality than wild-type ones (Figure 5A). At the end of the experiment, a total of 58 wild-type oysters and 35 selected oysters were found dead.

Examination of heart imprints allowed detecting Bonamia ostreae in some challenged flat oysters (Figure 5B). More infected oysters were reported among the wild-type group (42 positive oysters/166 oysters analyzed: $25 \%$ ) than in the selected group (29 positive oysters/178 oysters analyzed: 16\%) (Table 1A). Among challenged wild-type oysters 27 oysters appeared lightly infected $(\mathrm{Bo}+)$ and 15 oysters showed high level of infection $(\mathrm{Bo}++)$. Among challenged selected oysters 24 oysters were found lightly infected $(\mathrm{Bo}+)$ and 5 appeared highly infected significantly different to wild type oyster. According to our infection level scale, no very highly infected oyster $(\mathrm{Bo}+++)$ was detected whatever the oyster group was (Table 1A).

\section{Flow Cytometry Analyses}

Fluorescent bead phagocytosis was significantly lower in infected selected flat oysters compared to non-infected ones $(p<0.005$, Figure 6A). Non-specific esterase activities and ROS production did not present significant difference between tested conditions (Figures 6B,C).

\section{Gene Expression Results}

A significant over expression of Oe-Fas ligand gene $(p<$ 0.0001) was observed in infected selected and wild-type oysters (Figures 7A,B). The expression of Oe-EcSOD gene was significantly down regulated in infected selected oysters $(p<$ 0.0001) (Figure 7A).

\section{DISCUSSION}

Two types of experimental infections (injection of parasites and cohabitation with experimentally infected oysters) have been performed in the present study in order to investigate in vivo the responses of two groups of flat oysters (selected and wild-type) to the parasite Bonamia ostreae at the cellular and molecular level.

Experimental infections by injection of purified parasites have been widely used to study interactions between parasite and host and to develop selective breeding programs for resistance to bonamiosis. This method usually induces a high percentage of mortality associated with high levels of parasite detection (Tigé and Grizel, 1984; Elston et al., 1986; Mialhe et al., 1988; Naciri-Graven et al., 1998). Moreover, infection by injection allows subject oysters to a similar infection pressure, as they are inoculated with a similar defined amount of parasites. Despite these advantages, in vivo trial does not mimic the natural parasite entry pathway into the oysters.

In our study, we also carried out a cohabitation experiment to induce the parasitic disease. For this purpose, we used 
TABLE 1 | (A) General information about the infection level in challenged oysters. (B) Number of infected oysters along the experimental infection by injection.

\section{A}

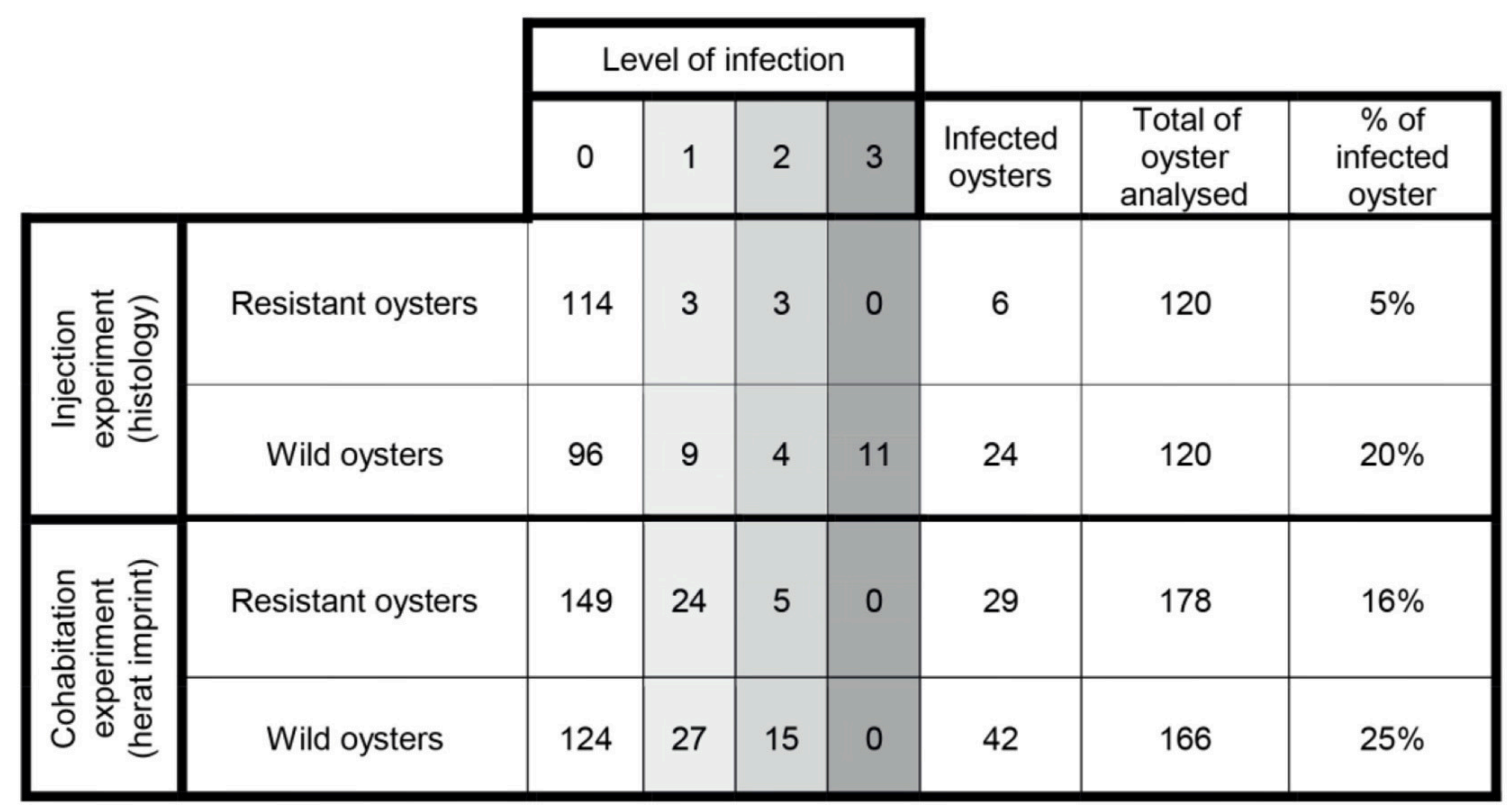

\begin{tabular}{|c|c|c|c|c|c|c|c|}
\cline { 2 - 8 } & $12 \mathrm{~h}$ & 3 days & 5 days & 8 days & 15 days & 30 days & $\begin{array}{c}\text { Total of infected } \\
\text { oysters }\end{array}$ \\
\hline Resistant oysters & 4 & 0 & 1 & 0 & 0 & 1 & 6 \\
\hline Wild oysters & 2 & 5 & 1 & 4 & 4 & 8 & 24 \\
\hline
\end{tabular}

experimentally infected oysters as the source of contamination of healthy oysters (Lallias et al., 2008). Cohabitation experiment is close to a natural infection but the parasite is only detected after 3 months of challenge and challenged oysters usually display higher heterogeneity of infection level (Lallias et al., 2008).

In the present study, selected flat oysters displayed lower mortality rates and parasite detection frequency than wildtype oysters. Observations of histological sections showed a wide distribution of the parasite in different tissues (including digestive gland, gills, mantle and gonad) in infected wild oysters. Infection was sometimes associated with haemocyte infiltration in wild-type oysters. On the contrary, in infected selected oysters, the infection appeared less spread out and the parasite was mainly observed in gills and digestive gland.

The dynamic of measured haemocyte activities in parasite injected oysters was different between wild and selected oysters. The latter showed a decrease of phagocytosis capacity followed by a decrease of ROS production. In contrast, wild oysters generally showed an increase of the different measured activities, first of ROS production, then phagocytosis capacity and lastly esterase activities.

Moreover, fluorescent bead phagocytosis was lower in infected selected oysters compared to non-infected ones whatever the type of experiment. No significant difference was observed between infected and non-infected wild type oysters except 15 days post-injection: infected oysters showed higher phagocytosis activity than controls. In a previous work, a decrease of phagocytosis was also observed $2 \mathrm{~h}$ after in vitro infection (Morga et al., 2011a). Although phagocytosis may allow parasite degradation, it also contributes to the establishment and spread of Bonamia ostreae infection in target cells, the haemocytes. By decreasing phagocytosis activity, selected oysters might be able to reduce disease development. Wild infected oysters tended to increase their haemocyte activities while the selected infected oysters seemed to decrease their phagocytosis capacity, which could be a way to avoid the spreading of the parasite. In cohabitation experiment, once the infection was well established, selected infected oysters maintained a lower level of phagocytosis capacity than selected non-infected oysters.

Non-specific esterases activities did not show significant differences between tested conditions except in wild-type oysters 30 days post-injection. Infected oysters showed higher esterase activities than controls, which could be related to the development of the infection and the activation of the host response.

Tested conditions did not affect ROS production during the cohabitation experiment whereas in the context of the injection experiment, differences were observed between infected and 


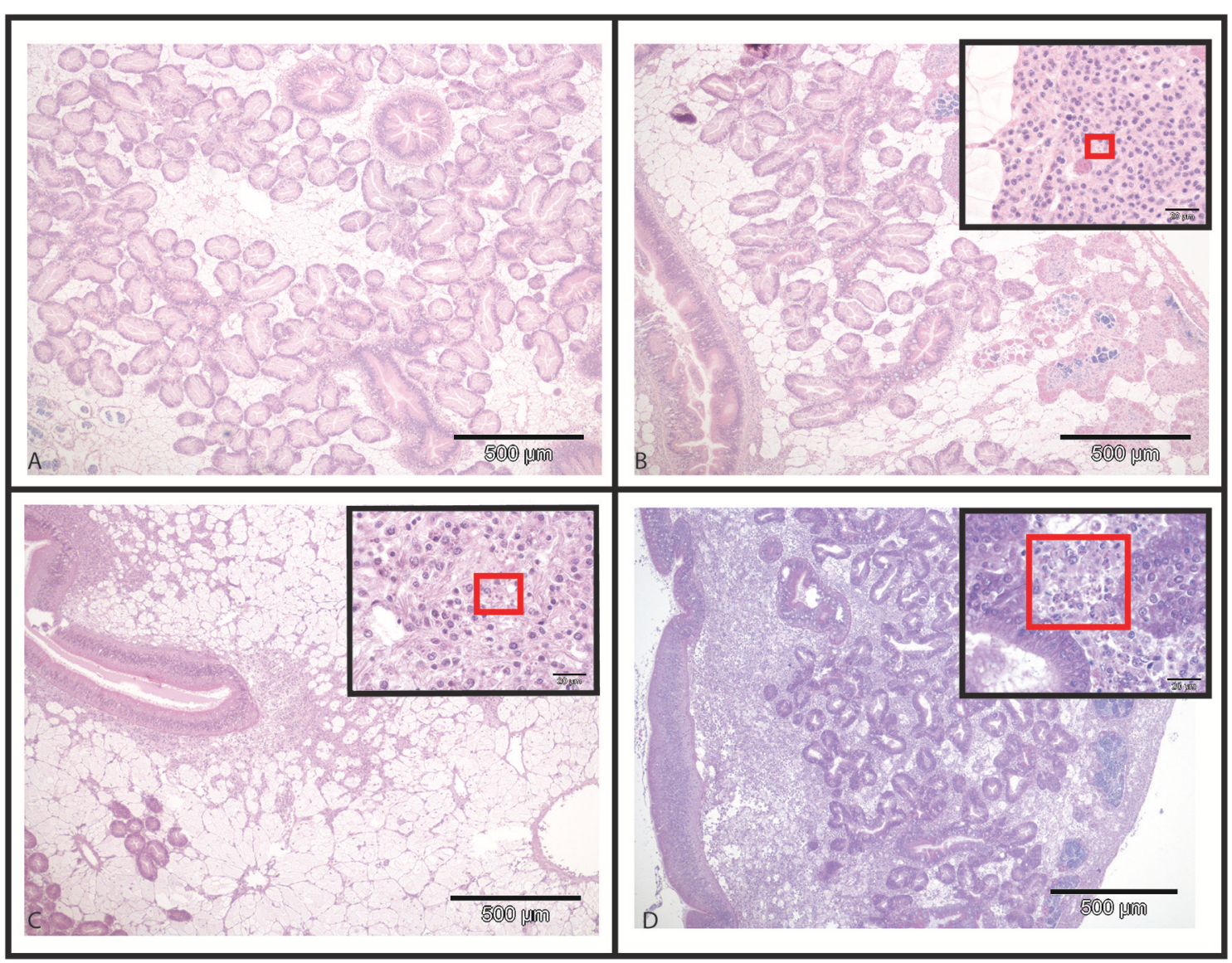

FIGURE 2 | Hematoxylin and Eosin stained histological slides from flat oysters Ostrea edulis. (A) Non-infected oyster displaying normal connective tissue around the digestive tubules. (B) Infected oyster showing low haemocytic infiltration in the connective tissue around the digestive tubules. Higher magnification shows the presence of Bonamia ostreae in haemocytes contributing to this haemocytic infiltration. (C) Infected oyster showing moderate haemocytic infiltration in the connective tissue along the stomach. Higher magnification shows the presence of Bonamia ostreae in haemocytes contributing to this haemocytic infiltration. (D) Infected oyster showing important haemocytic infiltration in the connective tissue around digestive tubules. Higher magnification shows the presence of numerous parasites.

non-infected oysters. Infected wild-type oysters produced more ROS 3 and 5 days post-injection, while infected selected oysters produced less ROS, especially 8 days and 30 days post-infection. Reduced ROS production could be due to a decrease of the cellular damage. In contrast, in infected wild-type oysters, an important production of ROS was observed. This increase in ROS production may be linked to a higher presence of the parasite compared to selected oysters as shown by histological observation.

Expression levels of four genes were monitored during the experimental infections. These genes were previously identified in the context of in vitro infections (Morga et al., 2010, 2011a,b, 2012).

Two genes are related to the respiratory burst and antioxidant response (OeSOD and OeEc-SOD) and the other two genes belong to the apoptosis pathway (Oe-Fas ligand and OeIAP). SOD enzymes (cytoplasmic or extracellular) are known to be involved in the oxidative stress response through $\mathrm{O}_{2}^{-}$.detoxification. $\mathrm{O}_{2}^{-}$is toxic for pathogen agents and haemocytes as well.
FSW injected selected or wild oysters did not show significant modulation in time.

In selected oysters injected with the parasite, the first significant observed modulation was an increased expression of OeFas-ligand at 3 and 5 days post-injection, followed by an up regulation of OeIAP and OeSOD after 5 days. OeEcSOD expression appeared significantly down-regulated after 8 days post-infection. The wild oysters injected with the parasite displayed more diverse responses but did not show an increase of expression of genes related to apoptosis. On the contrary these genes as well as the OeSOD appeared under expressed at 3 and 5 days. The observed over-expression of OeFas-ligand 3 days post-injection in selected infected oysters may indicate that resistance to bonamiosis partly relies on apoptosis, which contributes to destroy infected cells. The expression of the OeEcSOD was generally decreased during the experiment in the selected infected oysters.

In wild infected oysters, the parasite seems to inhibit OeIAP and OeSOD expression possibly to avoid its own degradation by haemocytes. The inhibition of oxygen 




FIGURE 3 | Histograms of flow cytometry (Esterase activity, ROS and phagocytosis) after an infection by injection. (A) Percentages of haemocytes positive for non-specific esterase activity during the experimental infection by injection. Values are means of three replicates and bars represent standard deviation. (SIBO, Selected oysters injected with Bonamia ostreae; SIFSW, Selected oysters injected with filter salt sea water; WIBO, Wild oysters injected with Bonamia ostreae; WIFSW, Wild oysters injected with filter salt sea water). *Indicates significant difference for WIBO compared to WIFSW. (B) Percentages of haemocytes positive for ROS during the experimental infection by injection. Values are means of three replicates and bars represent standard deviation. (SIBO, Selected oysters injected with Bonamia ostreae; SIFSW, Selected oysters injected with filter salt sea water; WIBO, Wild oysters injected with Bonamia ostreae; WIFSW, Wild oysters injected with filter salt sea water). *Indicates significant difference for WIBO compared to WIFSW or FIBO compared to SIFSW. (C) Percentages of haemocytes positive for phagocytosis during the experimental infection by injection. Values are means of three replicates and bars represent standard deviation. (SIBO, Selected oysters injected with Bonamia ostreae; SIFSW, Selected oysters injected with filter salt sea water; WIBO, Wild oysters injected with Bonamia ostreae; WIFSW, Wild oysters injected with filter salt sea water). *Indicates significant difference for WIBO compared to WIFSW or FIBO compared to SIFSW. 


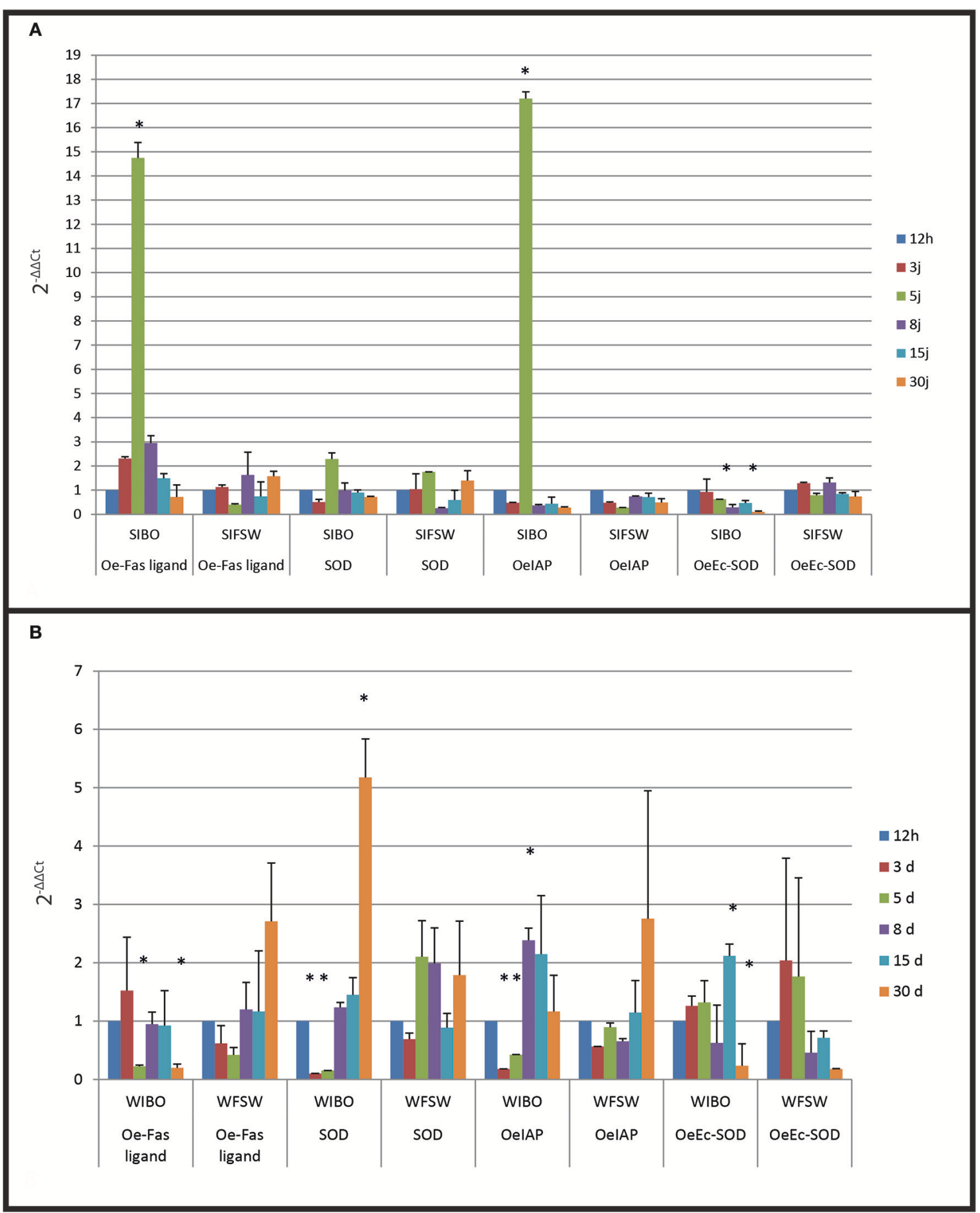

FIGURE 4 | Gene expression in selected oyster and in wild oyster after infection by injection. (A) Relative expression by quantitative PCR of selected transcripts in resistant oyster population (OelAP, OeFas-ligand, OeSOD, and OeEc-SOD) libraries. Expression levels were normalized to EF1- $\alpha$ and presented as relative expression to controls (mean $\pm \mathrm{SD}, n=3$ ). *Indicates significant differences of gene expression compared to controls. (SIBO: oysters injected with Bonamia ostreae, SIFSW: oysters injected with filter salt sea water). (B) Relative expression by quantitative PCR of selected transcripts in wild oyster population (OelAP, OeFas-ligand, OeSOD, andOeEC-SOD) libraries. Expression levels were normalized to EF1- $\alpha$ and presented as relative expression to controls (mean \pm SD, $n=3$ ). *Indicates significant differences of gene expression compared to controls. (WIBO, Wild oysters injected with Bonamia ostreae; WFSW, Wild oysters injected with filter salt sea water) 


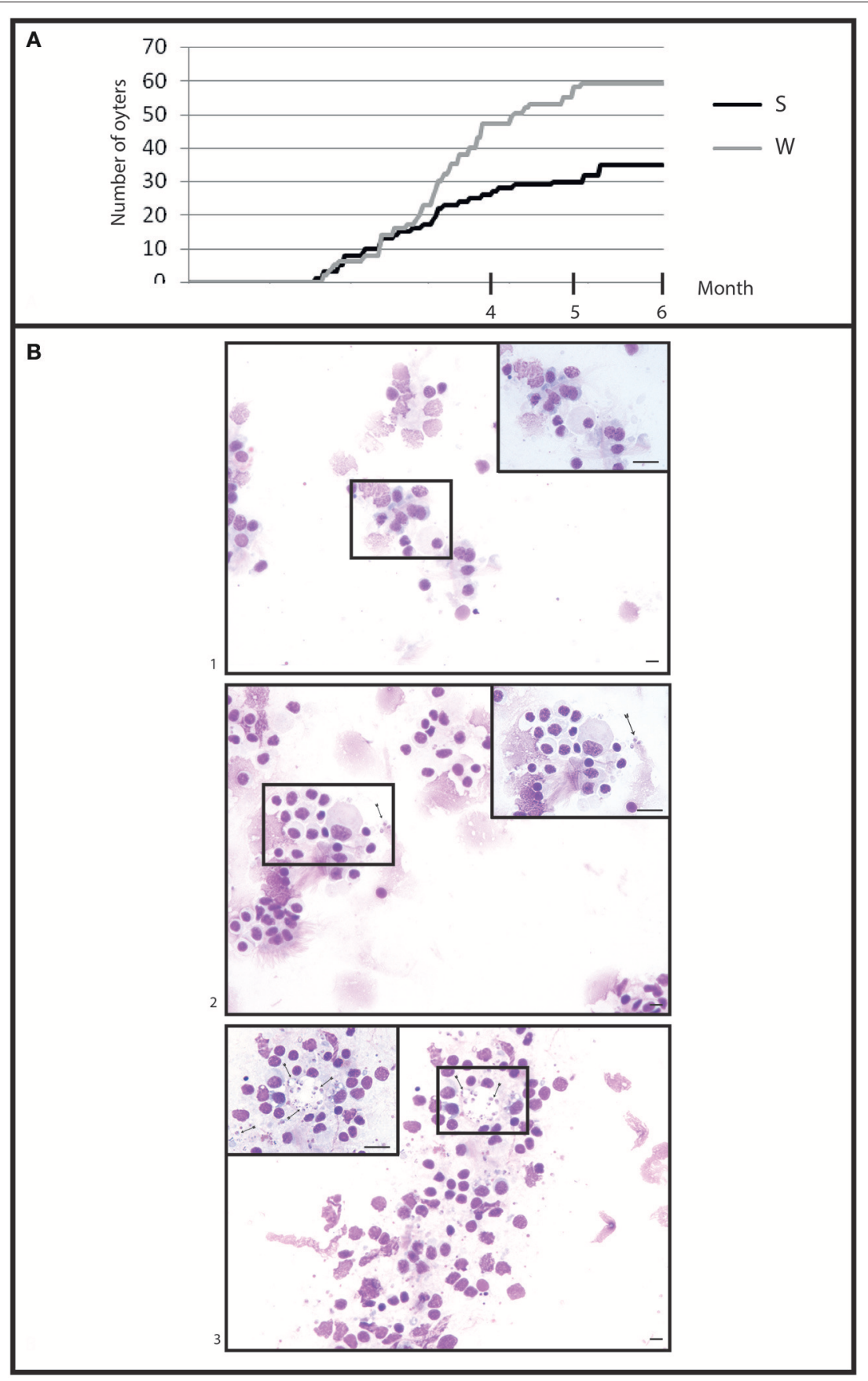

FIGURE 5 | General information in infection by cohabitation. (A) Cumulative mortality during 6 month of cohabitation in (S) selected oyster population and (W) wild oyster population. (B) Heart imprint (1) low infections (BO+), (2) moderate infections (BO++), (3) heavy infections (B0+++).

radical production has already been described in other host-parasite models and facilitates intracellular survival of protozoan parasites including Trypanosoma spp. (Penketh et al., 1987), Toxoplasma spp. (Murray et al., 1980; Shrestha et al., 2006), Leishmania spp. (Murray, 1981), B. ostreae (Morga et al., 2009) and P. marinus (Volety and Chu, 1995).
In the cohabitation experiment, both wild and selected infected oysters showed an increased expression of OeFas-ligand suggesting that the stimulation of apoptosis is a natural response of the oyster against the parasite. On the contrary, the decrease of OeEc-SOD was only observed in selected infected oyster and may be related to the decrease of phagocytosis observed in these oysters. 


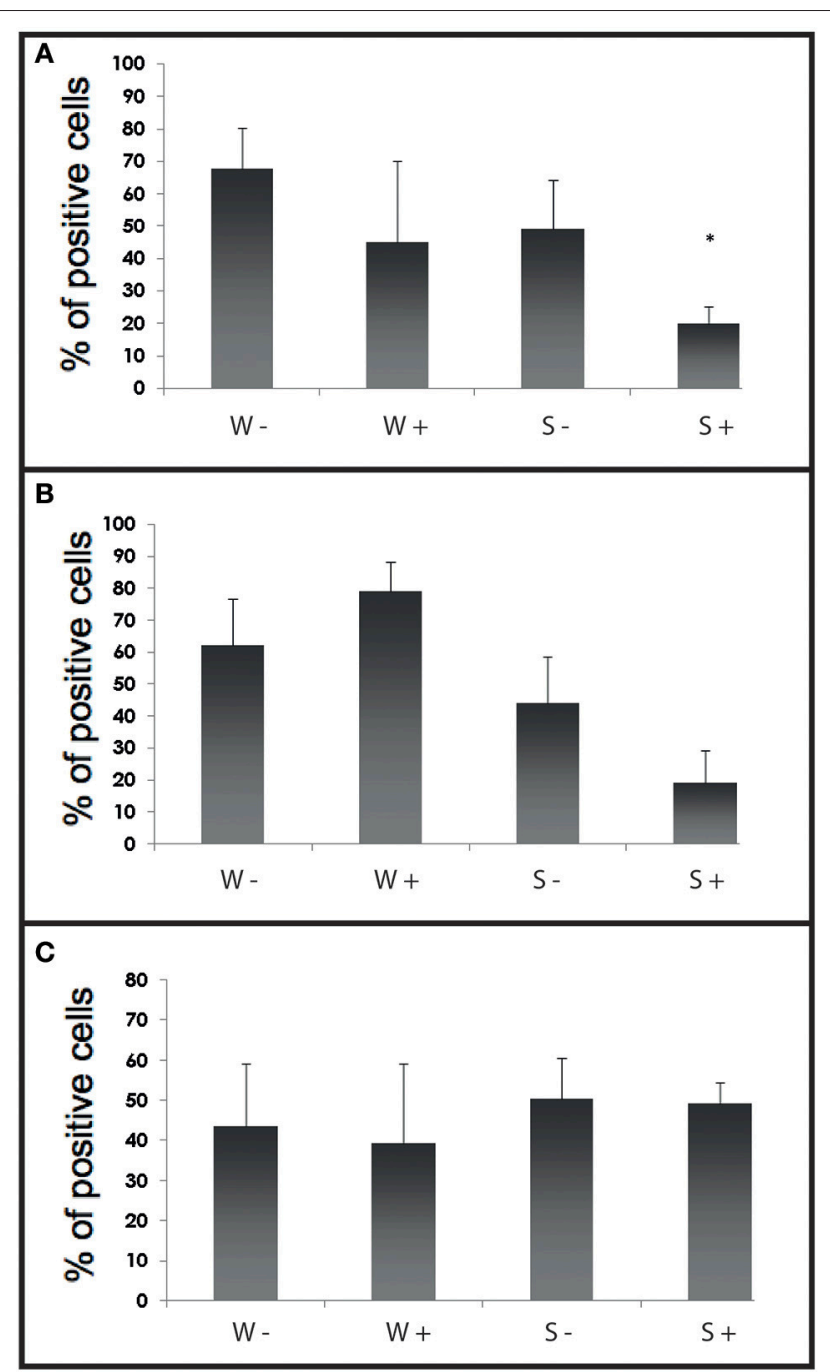

FIGURE 6 | Histograms of flow cytometry (Esterase activity, ROS and phagocytosis) after an infection by cohabitation. (A) Percentages of haemocytes positive for phagocytosis during the experimental infection by cohabitation. Values are means of three replicates and bars represent standard deviation. W- (Wild haemolymph pool of free of parasite), $W_{+}$(wild haemolymph pool infected with the parasite Bonamia ostreae), S- (Selected haemolymph pool of free of parasite), S+ (selected haemolymph pool infected with the parasite Bonamia ostreae). (B) Percentages of haemocytes positive for non-specific esterase activity during the experimental infection by cohabitation. Values are means of three replicates and bars represent standard deviation. W- (Wild haemolymph pool of free of parasite), W+ (wild haemolymph pool infected with the parasite Bonamia ostreae), S- (Selected haemolymph pool of free of parasite), $\mathrm{S}+$ (selected haemolymph pool infected with the parasite Bonamia ostreae). *Indicates significant difference for $\mathrm{S}+$ compared to S-. (C) Percentages of haemocytes positive for ROS during the experimental infection by cohabitation. Values are means of three replicates and bars represent standard deviation. W- Wild haemolymph pool of free of parasite), $W_{+}$(wild haemolymph pool infected with the parasite Bonamia ostreae), S- (Selected haemolymph pool of free of parasite), S+ (Selected haemolymph pool infected with the parasite Bonamia ostreae).

Although injection experiments allow to describe the development of the infection, this experimental approach does not take into consideration the whole pathogenesis process. On

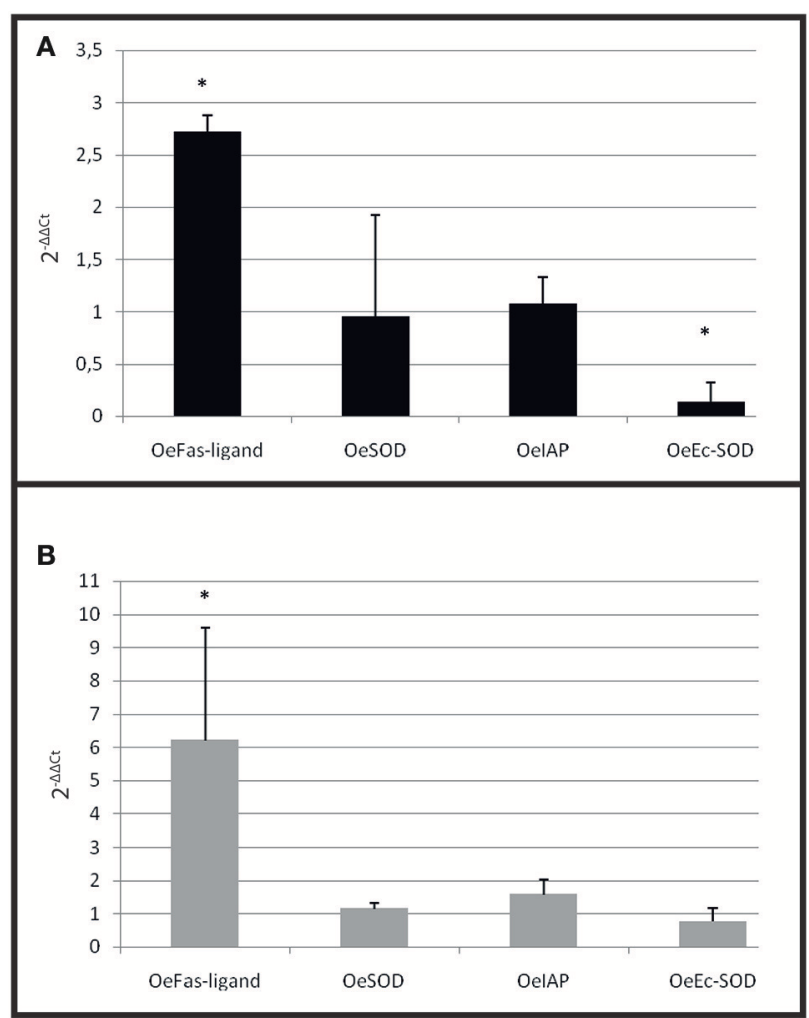

FIGURE 7 | Gene expression in resistant oyster and in wild oyster after infection by cohabitation. (A) Relative expression by quantitative PCR of selected transcripts in resistant infected oyster population (OelAP, OeFas-ligand, OeSOD andOeEc-SOD) libraries. Expression levels were normalized to EF1- $\alpha$ and presented as relative expression to controls (pool free of parasite) (mean $\pm \mathrm{SD}, n=2$ ). ${ }^{*}$ ndicates significant differences of gene expression compared to controls. (B) Relative expression by quantitative PCR of selected transcripts in wild infected oyster population (OelAP, OeFas-ligand, OeSOD, andOeEc-SOD) libraries. Expression levels were normalized to EF1- $\alpha$ and presented as relative expression to controls (pool free of parasite) (mean \pm $\mathrm{SD}, n=2$ ). *Indicates significant differences of gene expression compared to controls.

the contrary, cohabitation experiments allow to investigate all the interactions between parasites and the host, including the potential role of barriers like mucus or mantle in the response of the oysters to the disease. Perkinsus marinus is an important protistan parasite of the eastern oyster Crassostrea virginica. Recent findings showed that oyster pallial organs (mantle, gills) are a major portal of entry for the parasite Pales Espinosa et al., 2013, 2014).

Selected and wild oysters in contact with infected oysters showed differences of mortality rate as well as differences of prevalence and infection level. However, compared to the injection experiment, the response of the oysters appeared to be more variable and delayed in time.

These experimental challenges contributed to investigation the response of selected and wild oysters during the course of an infection through the injection of parasites and through cohabitation with infected oysters. We observe a difference of the response according the two flat oyster groups tested however 
the difference is not always clear. This small difference could be due to the use of flat oyster from Quiberon; Flat oysters are long-exposed, and may have been selected to some extent. If the wild-type population has not been exposure to $B$. ostreae, the difference between both populations is stronger.

As soon as 3 and 5 days post-infection, infected selected oysters are able to decrease their phagocytosis capacity and increase the transcription of genes related to the apoptosis. These results could explain the lower level of infection and prevalence observed in these oysters. Decrease of phagocytosis activity and modulation of apoptosis induced by the parasite and/or by the oyster appear as two of the key mechanisms supporting resistance to bonamiosis. The parasite seems to be more able to infect flat oyster than cupped oyster haemocytes and the apoptotic response was more important against live than dead parasites in the natural host than in C. gigas. These results suggest that $O$. edulis specifically responds to $B$. ostreae by inducing apoptosis of haemocytes. These results give new perspectives in the understanding and the management of the disease and might

\section{REFERENCES}

Arzul, I., Langlade, A., Chollet, B., Robert, M., Ferrand, S., Omnes, E., et al. (2011). Can the protozoan parasite Bonamia ostreae infect larvae of flat oysters Ostrea edulis? Vet. Parasitol. 179, 69-76. doi: 10.1016/j.vetpar.2011.01.060

Arzul, I., and Carnegie, R. B. (2015). New perspective on the haplosporidian parasites of molluscs. J. Invertebr. Pathol. 131, 32-42. doi: 10.1016/j.jip.2015.07.014

Balouet, G., Poder, J., and Cahour, A. (1983). Haemocytic parasitosis: morphology and pathology of lesions in the French flat oyster, Ostrea edulis L. Aquaculture 34, 1-14. doi: 10.1016/0044-8486(83)90287-9

Bustin, S. A., Benes, V., Garson, J. A., Hellemans, J., Huggett, J., Kubista, M., et al. (2009). The MIQE guidelines: minimum information for publication of quantitative real-time PCR experiments. Clin. Chem. 55, 611-622. doi: $10.1373 /$ clinchem.2008.112797

Cavalier-Smith, T., and Chao, E. E. (2003). Phylogeny and classification of phylum Cercozoa (Protozoa). Protist 143, 341-358. doi: 10.1078/143446103322454112

Chagot, D., Boulo, V., Hervio, D., Mialhe, E., Bachere, E., Mourton, C. et al. (1992). Interactions between Bonamia ostreae (Protozoa: Ascetospora) and hemocytes of Ostrea edulis and Crassostrea gigas (Mollusca: Bivalvia): entry mechanisms. J. Invertebr. Pathol. 5, 241-249. doi: 10.1016/0022-2011(92) 90128-Q

Cochennec-Laureau, N., Auffret, M., Renault, T., and Langlade, A. (2003). Changes in circulating and tissue-infiltrating hemocyte parameters of European flat oysters, Ostrea edulis, naturally infected with Bonamia ostreae J. Invertebr. Pathol. 83, 23-30. doi: 10.1016/S0022-2011(03)00015-6

Culloty, S. C., Cronin, M. A., and Mulcahy, M. F. (2004). Potential resistance of a number of populations of the oyster Ostrea edulis to the parasite Bonamia ostreae. Aquaculture 237, 41-58. doi: 10.1016/j.aquaculture.2004.04.007

Culloty, S. C., and Mulcahy, M. F. (1996). Season-, age-, and sex-related variation in the prevalence of bonamiasis in flat oysters (Ostrea edulis L.) on the south coast of Ireland. Aquaculture 144, 53-63. doi: 10.1016/S0044-8486(96) 01290-2

Culloty, S. C., Novoa, B., Pernas, M., Longshaw, M., Mulcahy, M. F., Feist, S. W., et al. (1999). Susceptibility of a number of bivalve species to the protozoan parasite Bonamia ostreae and their ability to act as vectors for this parasite. Dis. Aquat. Org. 37, 73-80. doi: 10.3354/dao037073

Elston, R. A., Farley, C. A., and Kent, M. L. (1986). Occurrence and significance of bonamiasis in European flat oysters Ostrea edulis in North America. Dis. Aquat. Org. 2, 49-54. doi: 10.3354/dao002049

Food and Agriculture Organization of the United Nations (2010). FishStat. Available online at: http://www.fao.org/fi/statist/FISOFT/FISHPLUS.asp contribute to identify new target for the development of selection programme.

\section{AUTHOR CONTRIBUTIONS}

BM, TR, NF, SoL, CG, BC, JJ, SyL EH, and IA contributed to the conception of the work. BM, TR, NF, SoL, CG, BC, and JJ acquired and analyzed the data for the work. BM, TR, and IA interpreted the data. BM, TR, and IA drafted the work.

\section{ACKNOWLEDGMENTS}

The Région of Poitou-Charentes supported in part this research. The authors thank Raphael Brizard and all technicians of Ifremer's facilities in La Tremblade for technical assistance for oyster maintenance and Ifremer's hatchery from Argenton (Brittany, France) for supplying selected oysters. The authors are very grateful to Dr. Colleen Burge and Mrs Estelle Delangle for revising the manuscript.

Gervais, O., Chollet, B., Renault, T., and Arzul, I. (2016). Flat oyster follows the apoptosis pathway to defend against the protozoan parasite Bonamia ostreae. Fish Shellfish Immunol. 56, 322-329. doi: 10.1016/j.fsi.2016.07.021

Hervio, D., Bachère, E., Boulo, V., Cochennec, N., Vuillemin, V., Le Coguic, Y., et al. (1995). Establishment of an experimental infection protocol for the flat oyster, Ostrea edulis, with the intrahaemocytic protozoan parasite, Bonamia ostreae: application in the selection of parasite-resistant oysters. Aquaculture 132, 183-194. doi: 10.1016/0044-8486(94)00342-L

Hervio, D., Chagot, D., Godin, P., Grizel, H., and Mialhe, E. (1991). Localization and characterization of acid phosphatase activity in Bonamia ostreae (Ascetospora), an intrahemocytic protozoan parasite of the flat oyster Ostrea edulis (Bivalvia). Dis. Aquat. Org. 11, 67-70.

Jaziri, H. (1985). Biogéographie et Polymorphisme Enzymatique chez l'huître Plate Ostrea edulis L. 1758. Master's thesis, University of Montpellier, Montpellier

Lallias, D., Arzul, I., Heurtebise, S., Ferrand, S., Chollet, B., Robert, M., et al. (2008). Bonamia ostreae-induced mortalities in one-year old European flat oysters Ostrea edulis: experimental infection by cohabitation challenge. Aquat. Living Resour. 21, 423-439. doi: 10.1051/alr:2008053

Lapègue, S., Bédier, E., Goyard, E., Dégremont, L., Baud, J. P., Gérard, A., et al. (2004). "Apport d'un programme de génétique à une filière de production aquacole: l'exemple de l'ostréiculture," in Styli 2003. Trente ans de Crevetticulture en Nouvelle-Calédonie, eds C. Goarant, Y. Harache, A. Herbland, and C. Mugnier (Plouzané: Ifremer), 113-121.

Lynch, S. A., Armitage, D. V., Wylde, S., Mulcahy, M. F., and Culloty, S. C. (2005). The susceptibility of young, prespawning oysters, Ostrea edulis, to Bonamia ostreae. J. Shellfish Res. 24, 1019-1025. doi: 10.2983/07308000(2005)24[1019:TSOYPO]2.0.CO;2

Mialhe, E., Bachère, E., Chagot, D., and Grizel, H. (1988). Isolation and purification of the protozoan Bonamia ostreae (Pichot et al. 1980), a parasite affecting the flat oyster Ostrea edulis L. Aquaculture 71, 293-299. doi: 10.1016/0044-8486(88)90198-6

Morga, B., Arzul, I., Chollet, B., and Renault, T. (2009). Infection with the protozoan parasite Bonamia ostreae modifies in vitro haemocyte activities of flat oyster Ostrea edulis. Fish Shellfish Immunol. 26, 836-842. doi: 10.1016/j.fsi.2009.03.018

Morga, B., Arzul, I., Faury, N., and Renault, T. (2010). Identification of genes from flat oyster Ostrea edulis as suitable housekeeping genes for real time PCR. Fish Shellfish Immunol. 29, 937-945. doi: 10.1016/j.fsi.2010.07.028

Morga, B., Arzul, I., Segarra, A., Faury, N., Chollet, B., and Renault, T. (2011a). Molecular responses of Ostrea edulis haemocytes to an in vitro infection with Bonamia ostreae. Dev. Comp. Immunol. 35, 323-333. doi: 10.1016/j.dci.2010.10.005 
Morga, B., Renault, T., Faury, N., and Arzul, I. (2012). New insight in flat oyster Ostrea edulis resistance against the parasite Bonamia ostreae. Fish Shellfish Immunol. 32, 958-968. doi: 10.1016/j.fsi.2012.01.026

Morga, B., Renault, T., Faury, N., Chollet, B., and Arzul, I. (2011b). Cellular and molecular responses of haemocytes from Ostrea edulis during kinetic in vitro infection by the parasite Bonamia ostreae. Int. J. Parasitol. 41, 755-764. doi: 10.1016/j.ijpara.2011.01.013

Mourton, C., Boulo, V., Chagot, D., Hervio, D., Bachere, E., Mialhe, E., et al. (1992). Interactions between Bonamia ostreae (Protozoa: Ascetospora) and hemocytes of Ostrea edulis and Crassostrea gigas (Mollusca: Bivalvia): in vitro system establishment. J. Invertebr. Pathol. 59, 235-240. doi: 10.1016/0022-2011(92)90127-P

Murray, H. W. (1981). Susceptibily of leishmania to oxygen intermediate and killing by normal macrophage. J. Exp. Med. 153, 1302-1315.

Murray, H. W., Nathan, C. F., and Cohn, Z. A. (1980). Macrophage oxygendependent antimicrobial activity. J. Exp. Med. 152, 1610-1624.

Naciri-Graven, Y., Martin, A. G., Baud, J. P., Renault, T., and Gérard, A. (1998). Selecting the flat oyster Ostrea edulis (L.) for survival when infected with the parasite Bonamia ostreae. J. Exp. Mar. Biol. Ecol. 224, 91-107. doi: 10.1016/S0022-0981(97)00171-8

Pales Espinosa, E., Corre, E., and Allam, B. (2014). Pallial mucus of the oyster Crassostrea virginica regulates the expression of putative virulence genes of its pathogen Perkinsus marinus. Int. J. Parasitol. 44, 305-317. doi: 10.1016/j.ijpara.2014.01.006

Pales Espinosa, E., Winnicki, S., and Allam, B. (2013). Early host-pathogen interactions in a marine bivalve: Crassostrea virginica pallial mucus modulates Perkinsus marinus growth and virulence. Dis. Aquat. Org. 104, 237-247. doi: 10.3354/dao02599

Penketh, P. G., Kennedy, W. P. K, Palton, C. L., and Sartorelli, A. C. (1987). Trypanosomatid hydrogen peroxyde metabolism. FEBS Lett. 221, 427-431.
Pfaffl, M. W. (2001). A new mathematical model for relative quantification in real-time RT-PCR. Nucleic Acids Res. 29, 2002-2007. doi: 10.1093/nar/29.9.e45

Pichot, Y., Comps, M., Tigé, G., Grizel, H., and Rabouin, M. A. (1979). Research on Bonamia ostreae gen. n., sp. n., a new parasite of the flat oyster Ostrea edulis (L.). Rev. Trav. Inst. Pêches Marit. 43, 131-140.

Sierra, R., Canas-Duarte, S. J., Burki, F., Schwelm, A., Fogelqvist, J. N., Dixelius, C., et al. (2016). Evolutionary origins of rhizarian parasites. Mol. Biol. Evol. 33, 980-983. doi: 10.1093/molbev/msv340

Shrestha, S. P., Tomita, T., Weiss, L. M., and Orlofsky, A. (2006). Proliferation of Toxoplasma gondii in inflammatory macrophages in vivo is associated with diminished oxygen radical production in the host cell. Int. J. Parasitol. 36, 433-441. doi: 10.1016/j.ijpara.2006.01.006

Tigé, G., and Grizel, H. (1984). Essai de contamination d'Ostrea edulis Linné par Bonamia ostreae (Pichot et al., 1979) en rivière de Crach (Morbihan). Rev. Trav. Inst. Pêches Marit. 328, 3-13.

Volety, A. K., and Chu, F. L. (1995). Suppression of chemiluminescence of eastern oyster (Crassostrea virginica) hemocytes by the protozoan parasite Perkinsus marinus. Dev. Comp. Immunol. 19, 135-142.

Conflict of Interest Statement: The authors declare that the research was conducted in the absence of any commercial or financial relationships that could be construed as a potential conflict of interest.

Copyright (c) 2017 Morga, Renault, Faury, Lerond, Garcia, Chollet, Joly, Lapègue, Harrang and Arzul. This is an open-access article distributed under the terms of the Creative Commons Attribution License (CC BY). The use, distribution or reproduction in other forums is permitted, provided the original author (s) or licensor are credited and that the original publication in this journal is cited, in accordance with accepted academic practice. No use, distribution or reproduction is permitted which does not comply with these terms. 